\title{
Best practices in patent license negotiations
}

\author{
Jennifer Giordano-Coltart \& Charles W Calkins \\ There's a lot to consider before out-licensing patent rights. Here, a law student and a seasoned patent attorney \\ outline what every bioentrepreneur should know before tackling the task.
}

\begin{abstract}
icensing is an inherent part of the biotech/ Lpharmaceutical business. Traditionally, patent licensing has taken place in joint development agreements, for commercializing and or producing small- and large-molecule therapeutics. In addition, the emergence of genetic testing to assist in diagnosing and treating disease has resulted in analytical laboratories seeking licenses to intellectual property (IP) for isolated genes. As negotiations are often a key determinant in the quality of a licensing transaction, we break down the process here into three parts and provide tips and advice for each stage.
\end{abstract}

\section{Setting the table}

Understanding your objectives is a necessary first step to any negotiation. You might be seeking help for a developed technology that you lack the resources to market and instead want to out-license to raise cash. Alternatively, perhaps you have a promising technology with a proven track record in the clinic that would now benefit from a joint development agreement to bring it to market. Or maybe you need to in-license a technology to produce it in commercial quantities.

Whatever the reason, your team should include a business development executive, a scientific-technical expert, a decision maker and a licensing attorney. The business development executive (sometimes the CEO at smaller firms, or a technology transfer professional at a university) usually finds the deal, brings the parties together and keeps the process moving.

Jennifer Giordano-Coltart is at the Duke University School of Law, Science Drive and Towerview Road, Durham, North Carolina 27708, USA. Charles W Calkins is at Kilpatrick Stockton LLP, 1001 West Fourth Street, WinstonSalem, North Carolina 27101, USA. e-mail: giordano-coltart@law.duke.edu or ccalkins@kilpatrickstockton.com

\section{Box 1 Proprietary position}

Your proprietary position will affect your ability to negotiate and obtain favorable terms. Your position is a combination of the strength of your IP portfolio (primarily patents) and the strength of third-party (often not a party to the license) IP. Strong proprietary positions (e.g., composition-of-matter patents covering your technology) can be weakened by the existence of third-party patents that may also cover, or potentially cover, your composition, or its method of use or manufacture.

If you are a licensor, it can be very useful for the negotiation if you perform a freedomto-practice search to discover third-party patents that cover, or are close to covering, all or part of your technology. In some cases, this can also help you find a potential partner by identifying others working in similar technology.

If you are a licensee, a freedom-to-practice search should be a part of basic due diligence. If licensing the technology at issue will result in a weak proprietary position, you should determine whether your position can be strengthened by filing new patents or by licensing potentially problematic third-party patents. You may also need to be willing to reduce your potential return from licensing by a portion of the amount of royalties the licensee needs to pay to third parties. A weaker proprietary position is a factor that licensees can use to negotiate for smaller fees and royalties because large payment obligations, in addition to lack of significant exclusivity, decreases market competitiveness and harms future market success.

The scientific-technical expert provides scientific and technological expertise and conducts due diligence research relating to the technology at issue. And the decision maker must have authority to commit your party to particular deal terms. In our opinion, document drafting is often easier when an attorney has the benefit of participating in negotiations and understands the positions of both sides. Once the team is in place, it's important to meet and reach an understanding of the motivation for the deal and to go over each member's responsibilities.

Next, assess your standing, as well as that of the other party, including the strength of your proprietary position (Box 1). In addition, your team should evaluate and determine your own marketing, technical, sales and services strengths as well as the strengths of the other party in the field of the patented technology_all are relevant to licensing fee amounts and royalties to be paid back to the patent holder. These and other contract provisions will help the parties define the scope of the licensed technology and their competitiveness as potential licensing partners. Furthermore, your team should carefully evaluate potential best alternatives to the license.

Another important aspect is to decide which terms and conditions can be omitted from preliminary talks between the parties until formal negotiations begin. This is key until detailed negotiations begin because it is difficult to perceive the true value of any license, and, thus, talks may unnecessarily break down due to discouragement over early positions that seem highly objectionable.

What's more, you might find it helpful to exchange a term sheet before the initial negotiation. The term sheet typically outlines the major issues in a potential deal. These include the following: the licensed product or process; licensed territory; preliminary thoughts on fees 
and royalties; technical information and training required to develop and manufacture, sell and service the licensed product (and who will be responsible for the same); sales and service support; degree of exclusivity; and duration of the license.

The negotiation process at times can be a drawn-out affair, so establish some deadlines to help keep the process moving. Parties that cannot meet deadline requirements will not commit to reaching an agreement, which should allow you to cut your losses early and look elsewhere for a partner. Draw up deadlines for the initial meeting, for drafting the letter of understanding, for executing the letter, for reviewing the draft agreement, for making revisions, for finalizing the licensing agreement and then for executing it.

For the negotiation itself, in addition to a nondisclosure agreement, you will also require a 'joint privilege agreement' if you intend to discuss legal opinions and avoid waiving the attorney-client privilege (Box 2).

Once a preliminary agreement is reached, present a letter of understanding to the other party as soon as possible. The document will typically include provisions addressing the definition of licensed product, the license grants, the licensed territory, exclusivity, the license fee and royalty, any technical information and assistance, the duration of the license and an express indication that the letter of understanding is a nonbinding legal instrument.

When all of this is done, start drafting the contract. Some argue that the party doing the drafting is in the more favorable position because it can include desirable provisions and make the other party defend requests for modification. But we feel that the nondrafting party usually has little issue raising objections to drafts. In addition, the nondrafting party might gain valuable insights into the other party's positions by making the other party 'go first.' Drafters should include many minor provisions that can be given up easily, whereas nondrafters should aim to revise major provisions first.

\section{The negotiation}

The terms of a licensing contract reflect the allocation of risk between the parties (http:// www.patenthawk.com/valuation.htm). If you have taken a molecule through one or more phases of clinical work, or have the financial resources to do so, you likely will be in position to negotiate a narrow licensing agreement that gives an incentive for development and marketing of the technology and that enables additional licensing agreements for other markets. Without clinical data, your position is much weaker.
Remember too that your potential partner wants an exclusive license with the broadest rights for the least amount of money. Licensees are also concerned with product liability and patent infringement indemnification, so you should expect a fully developed, detailed business plan from your potential licensee that justifies the provisions it seeks by estimating profits and costs.

The truth is, though, that there is no easy answer to determining the value of a particular technology. Every molecule is potentially the next blockbuster therapeutic. It's best to take a realistic view of the developmental stage and the investment needed to commercialize the technology. Companies and universities often fall into the trap of overvaluing early promising data (e.g., animal models) and losing sight of the additional $\$ 100$ million-plus required to determine efficacy and safety in humans. Thus, as licensor, you may need to reduce your expected return to make the licensee's expected return reasonable.

A rational approach is to develop a win-win scenario by looking at the actual investment return of each party. If the licensor has spent $\$ 10$ million to develop the compound, and the licensee will spend an additional $\$ 100$ million to commercialize it, negotiating a deal in which the licensor receives $10 \%$ of the return may be realistic, although the licensee may want a greater return based on assuming a greater risk (greater investment). Alternatively, where a licensed compound is ready for commercialization or is on the market, more standard accounting techniques may be used because the risk/return ratio can be more directly calculated.

You also need to be realistic about the return expected by your shareholders or university-a smaller return, particularly a smaller return in the near term, is often better than a 'potential' large return that never materializes or materializes years later.

Here's another bit of advice: when considering your technology as a licensor, aim to carve

\section{Box 2 Joint privilege/ common interest agreements}

During negotiations it might be helpful to discuss opinions of outside counsel, or the parties might inadvertently discuss such opinions. Those discussions, and/or the sharing of opinion documents, could constitute a waiver of the attorney-client privilege attached to the opinions and the related subject matter, thereby jeopardizing a party's position in any future litigation. A joint privilege/common interest agreement protects the parties by establishing that, for the purpose of the negotiations, the parties have a common interest. The agreement will generally set forth the common interest, describe the subject matter to be shared, include specific confidentiality provisions regarding the shared information and provide waivers so that the attorneys can continue to represent each party in any future dispute. Although a joint privilege/common interest agreement does not guarantee that a court will not find a waiver of the attorney-client privilege, an agreement provides a good basis for a defense against such waiver and should therefore always be considered. 
concurrently develop all possible uses or markets for the technology. Although the overall return may be lower, such a tradeoff may actually be worthwhile for a university because it brings in research funds and provides the opportunity for commercialization of a technology.

\section{Talking money}

There are several forms of payment in patent licensing deals. For example, when a university is the licensor, a typical license will include a signing fee, reimbursement and ongoing payment of patent prosecution costs, milestone payments, minimum annual royalties and a percentage royalty on sales. A university also might request that the licensee participate in sponsored research at the university. But for an emerging biotech company, a deal might include all that and also ask the partner to fund employee positions to work on further development of the licensed technology.

The license or signing fee-essentially the 'cost of admission' for your potential partner-helps you recoup some of your investment. It is always beneficial to seek a higher upfront payment rather than high royalties, and the amount of payment can indicate your partner's commitment to the technology. However, a high initial fee does not have to mean a lower royalty rate. Higher royalties may be justifiable if the initial fees and milestones are creditable against future royalties and the licensee will still make a reasonable return. Also, by building into the license annual or other periodic fees, which typically terminate when royalty payments begin, you can give your licensee an incentive to aggressively develop and market the technology.

Milestone payments are triggered by product or service developmental benchmarks, and they serve to compensate the licensor as the value of the licensed technology increases. Most, if not all, license agreements in the biotech/pharmaceutical space will require a licensee to use 'best efforts' to meet such benchmarks in specified time periods in taking the patented technology to market. Typical milestones include designation of a 'lead compound,' filing an investigational new drug application or a new drug application, completing a clinical trial phase, and first commercial sale. The amount of milestone payments differ, but should relate to the amount of investment required and the licensee's potential return on that investment in view of the increased value of the technology. If a licensee is unable to meet the milestones, the license might provide for the reversion of all of the license rights back to the licensor, or it might provide for loss of exclusivity in one or more fields of use or some combination of these. In later stages of development, milestone payments are commonly in the tens of millions of dollars as the licensee's potential return on their investment approaches.

Typical or standard royalties in the biotech/ pharmaceutical area cover a fairly broad range. For example, a small-molecule compositionof-matter patent can bring a royalty of $10-20 \%$, a large-molecule composition-of-matter patent $8-18 \%$ and method claims can bring 5-15\%. In the pharmaceutical industry, the current range for royalty rates is from $\sim 2 \%$ for a just discovered or engineered compound or material to $\sim 20 \%$ for a fully developed product approved for sale.

Be sure to require a minimum annual royalty payment, particularly after the early years of the license agreement. This should ensure your partner is aggressively marketing and selling the licensed technology. Minimum royalty payments are generally at the low end of your acceptable range for returns. You also might require the discretionary option of reducing the license rights if the minimum is not met. Where your partner has conducted royalty stacking-meaning it has licensed multiple different technologies from others and combined them into the final product or service-it might negotiate with its licensors to deduct some or all of the royalties paid to third parties from the amounts payable to each licensor. However, that is not particularly desirable to you (http://patentbaristas. com/archives/category/licensing/).

If you are financially weaker than your licensee, prepaid royalties, which can be weighed against future royalty obligations, may be attractive. That should help you recoup your monetary investment in the licensed technology, while not impairing the marketing ability of the licensee. Also, if you have confidence in the success of the licensee, you can try to negotiate for a higher royalty rate by risking no royalties if the technology fails to achieve its predictions. This is often useful for licenses for processes to improve efficiency or lower costs, where even marginal increases in efficiency can produce increased profits.

Subsequent filing of patent applications and correspondence with the US Patent and Trademark Office can be costly, as can international patent application filings for expansion into foreign markets. Thus, try to have your licensees take on the costs of maintaining the patent prosecution program, while you retain the associated rights.
Licensors also can seek supplemental remuneration or other types of income. Royalty payments may be reduced when the licensee can compensate you for the use of the technology in other ways. For example, the licensee may form a new corporate entity for the purpose of executing the license agreement in which you receive a percentage of the voting stock and a veto right on some decisions. That arrangement can compensate you by providing equity in the new corporation in exchange for the licensing rights and places you in a position to influence the conduct of a future market competitor. In addition, you can increase earning potential by requiring a percentage of the income from any sublicenses granted by the licensee.

The profitability of a license can also be increased if you can negotiate to provide special additional services for your partner, such as access to your premises, consulting, troubleshooting and sales or service support. Licensees can pay for service fees by annual retainers or per diem charges, though often a certain amount of services could be provided free of charge. Because you have a vested interest in seeing the licensed technology commercialized, if those services are not expressly provided for in the agreement, you can end up giving vast amounts of assistance and support with little or no consideration.

Both parties should negotiate provisions to address the ownership of any current or future improvements of the technology, although the rights negotiated will largely depend on circumstances before the contract: relative bargaining strength, developmental stage technology and potential market for new technologies (http://patentbaristas.com/ archives/category/licensing/).

\section{Conclusions}

Because of space limitations, this article has only provided a rough outline of license negotiation (for additional information or for further comments, readers are welcome to contact us). We hope we have illustrated that by approaching licensing transactions in a well-planned, forward-thinking manner, both licensees and licensors, particularly those with different types of expertise, can maximize mutual benefits and establish a framework for a solid working relationship in the future. The best practices outlined here provide perspective on the negotiation process as a whole and should aid parties contemplating licensing arrangements for biotechnological and pharmaceutical inventions in establishing the proper approach for the transaction. 